\author{
AMERICAN JOURNAL OF FOOD AND NUTRITION \\ Print: ISSN 2157-0167, Online: ISSN 2157-1317, doi:10.5251/ajfn.2011.1.1.28.33 \\ (c) 2011, ScienceHuß, http://www.scihub.org/AJFN
}

\title{
Chemical and microbiological evaluation of processed cheese available in Khartoum market, Sudan
}

\section{Tayseer Abd Elrahim Suleiman, Mohamed Osman Mohamed Abdalla, Nissreen Hassan Mohammed El Haj and Haifa Mukhtar Osman Elsiddig}

\author{
Department of Dairy Production, Faculty of Animal Production, University of Khartoum, \\ Shambat, Khartoum North, Sudan \\ Corresponding author: Mohamed Osman Mohamed Abdalla \\ Department of Dairy Production, Faculty of Animal Production, University of Khartoum, P.O. \\ Box 32, postal code 13314, Shambat, Khartoum North, Sudan \\ E-mail: abutahany@yahoo.com, Tel. :002491221869454
}

\begin{abstract}
This study was carried out to evaluate the chemical and microbiological quality of imported processed cheese available in the market. A total of 27 samples comprising three brands were collected from supermarkets in Khartoum market, Sudan during the period June-August, 2007. The samples were subjected to chemical analysis and microbiological examination. Results showed that fat, protein, ash and titratable acidity of cheese were not significantly affected by the time of sample collection, while the moisture content was high in samples of batch 3 . The brand of cheese showed no significant effect on all chemical composition under study (fat, protein, moisture, ash, titratable acidity). The fat content was $29.0-29.83 \%$, while protein content was 8.53-9.08\%, moisture content $49.33-54.17 \%$, ash content $2.35-2.85 \%$ and titratable acidity 0.60 $0.72 \%$. The total viable bacteria count was high in samples of batch 1 , while proteolytic bacteria count was high in samples of batch 2 and lipolytic bacteria count was high in samples of batch 3 and yeasts and moulds count was high in the samples of batch 1 . The total viable bacteria and lipolytic bacteria counts were high in brand $A$, while yeasts and moulds count was high in samples of brand $B$ and proteolytic bacteria count showed no significant variation between brands of cheese. Total viable bacteria were detected in all samples under study $(100 \%)$, while coliform bacteria were not detected $(0 \%)$, proteolytic bacteria were detected in $77.8 \%$, lipolytic bacteria in $74.2 \%$ and yeasts and moulds in $44.4 \%$.
\end{abstract}

Keywords: Processed cheese, evaluation, chemical, microbiological

\section{INTRODUCTION}

Processed cheese is a dairy product differing from the natural cheese in that it is not made directly from milk, although the main ingredient is the natural cheese. Processed cheese is made by blending shredded natural cheeses of different types and degrees of maturity with various ingredients and emulsifying agents (mostly sodium citrates, sodium orthophosphates or sodium polyphosphates), and optional ingredients such as butter or spices, followed by heating of the blend under a partial vacuum with constant agitation until a homogeneous mass is obtained (Mayer, 2001; Schar and Bosset, 2002).

Processed cheese can be made from a simple basic set of ingredients consisting of cheese, water and melting salts, or from a complex mix of ingredients including different types of proteins, fat, gums, stabilizers, flavourings and added minerals (Lee et al., 2003). For a typical industrial processed cheese production, the principal raw material is semi-mature cheese of shorter structure with partially hydrolyzed protein, and the processing markedly changes the structure of natural cheese and results in the development of new structures in the processed cheese (Piska and Štětina, 2004).

Kapoor and Metzger (2008) reported that there are various chemical and compositional properties which have an effect on the functional properties of process cheese, and that only standardizing the fat and moisture content of the cheese formulation does not ensure a product with the desired functional properties, so it is very important to control and monitor factors such as total calcium content, intact casein content, $\mathrm{pH}$, type and amount of emulsifying salts, lactose content, whey protein content and type and amount of rework added in order to produce a 
cheese with specific physicochemical and functional properties.

Many investigators reported that processed cheese may contain the following chemical composition: fat $13-37 \%$, protein $12.82-22.6$, moisture $38.2-64.21 \%$, ash $1.33-4.82$, titratable acidity $1.33-1.60$ and $\mathrm{pH}$ $4.4-6.3$ depending on the ingredients used in the manufacture of cheese (Acharya and Mistry, 2005; Kaminarides and Stachtiaris, 2000; Kapoor et al., 2007; Kwak et al., 2006; Shirashoji et al., 2006; Pinto et al., 2007).

The processed cheese is not a preserved food, but a 'semi-preserved food' with limited shelf life of 3-4 months, especially when the product is packaged in plastic foils, while products stored in metal cans may have longer shelf lives of 6-12 months at room temperature (Schär and Bosset, 2002).

Recently, processed cheese is imported from neighboring countries according to standards set by the government. Therefore, this investigation was conducted to study the chemical and microbiological quality of the imported processed cheese available in the market.

\section{MATERIALS AND METHODS}

Sampling and sample collection: A total of 27 imported processed cheese samples were collected from the supermarkets of Khartoum, Sudan. Cheese samples were collected from three different brands designated as $\mathrm{A}, \mathrm{B}$ and $\mathrm{C}$ comprising three companies during the months of June (batch 1), July (batch 2) and August (batch 3) $2007 . \quad$ The samples in cans were transported to the laboratory of the Department of Dairy Production, University of Khartoum and kept at $\leq 5^{\circ} \mathrm{C}$ till analysis was carried out. During the analysis, the cans were aseptically opened and chemical and microbiological analyses were carried out.

Compositional and chemical analysis: The fat content was determined by Gerber method (AOAC, 1990). Protein content was determined by Kjeldahl method according to method described by AOAC (2000). Moisture content was determined by gravimetric method (AOAC, 2000). Ash and titratable acidity were determined according to the method of AOAC (2000).

Microbiological examination: The samples were examined for total viable bacteria, coliform bacteria, proteolytic bacteria, lipolytic bacteria and yeasts and moulds. The media used were in a dehydrated form and prepared according to the manufacturer's instructions. Eleven grams of cheese were added to $99 \mathrm{ml}$ of sterile distilled water in a flask and shaken well to make $10^{-1}$ dilution. Further decimal dilutions were prepared in sterile distilled water. Total viable bacteria were enumerated by pour plate method using standard plate count agar (Houghtby et al., 1992) and the plates were incubated at $37^{\circ} \mathrm{C}$ for 48 hours. MacConkey agar was used for the enumeration of coliform bacteria and the plates were incubated at $37^{\circ} \mathrm{C}$ for 24 hours (Christen et al., 1992). Lipolytic bacteria were enumerated according to the method described by Zaki (1988) using nutrient agar medium and the plates were incubated at $37^{\circ} \mathrm{C}$ for 4 days. The lipolytic colonies were identified by copper sulphate $(20 \%)$ flooded after incubation. Proteolytic bacteria were counted according to Frank et al. (1992) using plate count agar plus $10 \%$ sterile skim milk. The plates were incubated at $37^{\circ} \mathrm{C}$ for 4 days. The total count of yeasts and moulds were determined according to Frank et al. (1992) using yeast extract agar, and the plates were incubated at $25^{\circ} \mathrm{C}$ for 5 days.

Statistical analysis: Statistical analysis was performed using the Statistical Analysis Systems (SAS, ver. 9). General Linear Models (GLM) were used to determine the effect of brand and batch on the chemical and microbiological quality of cheese. Means were separated using least significant difference at $\mathrm{P} \leq 0.05$.

\section{RESULTS AND DISCUSSION}

Processed cheese is a product of other types of cheese which might be of low quality from the start, and if the manufacturing conditions are not ideal the contamination might happen to the processed cheese. This study was intended to evaluate the processed cheese in the local market, and the philosophy behind this investigation was that the Sudanese market is open to foreign products, beside there is a trend of producing such products in Sudan. In addition, the imported products might be subjected to unfavourable environmental conditions such as storage and transportation which render the product unsafe and of low nutritional value, although the product is not yet expired.

Chemical composition: Results in table 1 show that fat, protein, ash and titratable acidity of cheese were not significantly affected by the time of sample collection (batch number) although fat content of samples collected in batch 3 was slightly higher, while protein content was slightly higher in batch 1 and ash and titratable acidity were slightly higher in 
samples of batch 2 . The moisture content was significantly $(P<0.001)$ higher in samples of batch 3 . The brand of cheese showed no significant effect on all chemical composition under study (fat, protein, moisture, ash, titratable acidity) (Table 2). The chemical composition of samples from the three brands within each batch of collection showed no significant variation except for ash content in batch 3 (Table 3). The fat content was $29.0-29.83 \%$, while protein content was $8.53-9.08 \%$, moisture content $49.33-54.17 \%$, ash content $2.35-2.85 \%$ and titratable acidity $0.60-0.72 \%$. The results of fat content in this study are in agreement with the findings of Kwak et al. (2002) who reported fat content of $29.0-33.0 \%$ in processed cheese made from cheddar cheese with different types and ratios of emulsifiers. The results are lower than values reported by Dimitreli and Thomarveis (2007), Acharya and Mistry (2005), Piska and Štětina (2004), Shirashoji et al. (2006) and Hanna and Nader (1996) and higher than the results obtained by Pinto et al. (2007), Kaminarides and Stechtaris (2000), Kapoor et al. (2007) and Abdel Razig and Yousif (2010). The protein content reported in this study is lower than the reports of Pinto et al. (2007) and Kaminarides and Stachtiaris (2000). The lower values of protein in this study might be due to the fact that the processed cheese in this study was made only from natural cheeses without additives such as whey retentates and concentrated and ultrafiltered milk. The protein content in other investigations reached as high as 31.3 - 34.8\% (Hanna and Nader, 1996). Acharya and Mistry (2005) reported the protein content of pasteurized process cheese made with condensed or ultrafiltered milk to be 19.6 - 22.6\%, while Abdel Razig and Yousif (2010) found the protein content of processed cheese made with groundnut milk to be $12.82-17.56 \%$. The moisture content of processed cheese is in line with Kaminarides and Stachtearis (2000) who reported moisture content of 49.74 50.5\%. However, Abdel Razig and Yousif (2010), Hanna and Nader (1996) and Piska and Štětina (2004) reported moisture content in processed cheese in the range of $51.0-64.21 \%$ which was higher than the values reported in this investigation. The ash content is in agreement with the values reported by Kwak et al. (2002) who reported ash content of $1.33-4.33 \%$, and in disagreement with Kaminarides and Stachtiaries (2000) and Acharya and Mistry (2005). The titratable acidity is lower than that reported by Pinto et al. (2007) and Abdel Razig and Yousif (2010).
Microbiological quality: The total viable bacteria count was higher $(P<0.001)$ in samples of batch 1 , while proteolytic bacteria count was high $(P<0.05)$ in samples of batch 2 and lipolytic bacteria count was high $(P<0.05)$ in samples of batch 3 and yeasts and moulds count was higher $(P<0.001)$ in the samples of batch 1 , while coliform bacteria were not detected in the samples of the three batches under study (Table 1). The total viable bacteria $(P<0.01)$ and lipolytic bacteria $(P<0.01)$ counts were higher in brand $A$, while yeasts and moulds count was high $(P<0.05)$ in samples of brand $B$ and proteolytic bacteria count showed no significant variation between brands of cheese (Table 2). The total viable bacteria count showed significant variation between the brands in batches 1 and 2 , while proteolytic bacteria count showed variation in samples of batches 2 and 3 and lipolytic bacteria and yeasts and moulds count showed variation in samples of batches 1 and 2 (Table 4). Total viable bacteria count was 1.48-2.33, proteolytic bacteria count was $0.600-1.340$, lipolytic bacteria count $0.217-1.164$ and yeasts and moulds count was $0-1.430 \log _{10} \mathrm{cfu} / \mathrm{gm}$. Total viable bacteria were detected in all samples under study $(100 \%)$, while coliform bacteria were not detected $(0 \%)$, proteolytic bacteria were detected in $77.8 \%$, lipolytic bacteria in $74.2 \%$ and yeasts and moulds in $44.4 \%$ (Table 5). The microbiological results indicated that the processed cheese samples collected during this investigation were of good microbiologcal quality since coliform bacteria were not detected and other microogoranisms were detected in some samples (in low numbers). Palmas et al. (1999) detected no coliform bacteria and Gramve psychrotrophs in processed spreads even after 3 months of storage, and yeasts (14.3\% of samples) and moulds ( $17.1 \%$ of samples) were detected in low frequency. Nour EIDiam and ElZubeir (2006) reported higher values of total bacteria $\left(6.0 \times 10^{6}-\right.$ $\left.6.5 \times 10^{7} \mathrm{cfu} / \mathrm{gm}\right)$, coliform bacteria $\left(1.4 \times 10^{4}-9.2 \mathrm{x}\right.$ $\left.10^{6} \mathrm{cfu} / \mathrm{gm}\right)$, psychrotrophic bacteria $\left(4.6 \times 10^{2}-9.1 \times\right.$ $\left.10^{3} \mathrm{cfu} / \mathrm{gm}\right)$ and yeasts and moulds $\left(3.6 \times 10^{4}-6.5 \mathrm{x}\right.$ $10^{5} \mathrm{cfu} / \mathrm{gm}$ ) in processed cheese made from Sudanese white cheese. Our results are in agreement with the findings of Aly et al. (1995) who reported that the total bacterial count of processed cheese never exceeded $600 \mathrm{cfu} / \mathrm{gm}$, proteolytic bacteria never exceeded $280 \mathrm{cfu} / \mathrm{gm}$ and lipolytic bacteria never exceeded $350 \mathrm{cfu} / \mathrm{gm}$ regardless of storage temperature or degree of substitution of mature cheese with ultrafiltered retentates. However, Kung et al. (2005) reported slightly higher values of aerobic plate count $\left(<1-4.56 \log _{10} \mathrm{cfu} / \mathrm{gm}\right)$ and 
total coliform bacteria $(<3-30 \mathrm{MPN} / \mathrm{gm})$ than those reported in the present investigation. The microbiological examination of processed cheese revealed good hygienic quality of the processed

Table 1. Chemical composition (\%) and microbiological quality $\left(\log _{10} \mathrm{cfu} / \mathrm{gm}\right)$ of three monthly batches of processed cheese

\begin{tabular}{|c|c|c|c|c|c|}
\hline \multirow{2}{*}{ Parameter } & \multicolumn{3}{|c|}{ Batch $^{1}$} & \multirow{2}{*}{ S.E } & \multirow{2}{*}{ S.L. } \\
\hline & 1 & 2 & 3 & & \\
\hline Fat & $29.22^{a}$ & $29.33^{a}$ & $29.50^{a}$ & 1.048 & N.S. \\
\hline Protein & $8.86^{a}$ & $8.77^{a}$ & $8.72^{\mathrm{a}}$ & 0.094 & N.S. \\
\hline Moisture & $49.78^{a}$ & $51.22^{b}$ & $53.72^{c}$ & 2.137 & $* * *$ \\
\hline Ash & $2.63^{a}$ & $2.67^{\mathrm{a}}$ & $2.64^{a}$ & 0.002 & N.S \\
\hline Titratable acidity & $0.653^{a}$ & $0.698^{a}$ & $0.622^{\mathrm{a}}$ & 0.107 & N.S \\
\hline Total viable bacteria & $2.11^{a}$ & $1.91^{a}$ & $1.52^{b}$ & 0.102 & $* * *$ \\
\hline Coliform bacteria & N.D & N.D & N.D & - & - \\
\hline Proteolytic bacteria & $0.971^{a}$ & $1.178^{\mathrm{a}}$ & $0.699^{b}$ & 0.307 & * \\
\hline Lipolytic bacteria & $0.833^{b}$ & $0.743^{\mathrm{C}}$ & $0.968^{a}$ & 0.294 & * \\
\hline Yeasts and moulds & $1.239^{a}$ & $0.210^{b}$ & $0.331^{b}$ & 0.264 & $* * *$ \\
\hline
\end{tabular}

Means within each row bearing the same superscripts are not significantly different $P>0.05$ )

${ }^{1}$ Batches 1, 2 and 3 were collected in three different months

** $=P<0.01$

* $\quad=\mathrm{P}<0.05$

N.S $=$ Not significant

$S . L=$ Significant level

$\mathrm{SE}=$ Standard error of means

ND: Not detected

Table 2. Chemical composition (\%) and microbiological quality ( $\log _{10}$ cfu/gm) of three brands of processed cheese

\begin{tabular}{|l|c|c|c|c|c|}
\hline \multirow{2}{*}{ Parameter } & \multicolumn{3}{|c|}{ Brand $^{1}$} & \multirow{2}{*}{ S.E } & \multirow{2}{*}{ S.L. } \\
\cline { 2 - 5 } & A & B & C & \\
\hline Fat & $29.44^{\mathrm{a}}$ & $29.28^{\mathrm{a}}$ & $29.33^{\mathrm{a}}$ & 1.048 & N.S. \\
\hline Protein & $8.78^{\mathrm{a}}$ & $8.92^{\mathrm{a}}$ & $8.81^{\mathrm{a}}$ & 0.094 & N.S. \\
\hline Moisture & $51.44^{\mathrm{a}}$ & $51.61^{\mathrm{a}}$ & $51.67^{\mathrm{a}}$ & 2.137 & N.S. \\
\hline Ash & $2.74^{\mathrm{a}}$ & $2.58^{\mathrm{a}}$ & $2.62^{\mathrm{a}}$ & 0.002 & N.S \\
\hline Titratable acidity & $0.658^{\mathrm{a}}$ & $0.649^{\mathrm{a}}$ & $0.667^{\mathrm{a}}$ & 0.107 & N.S \\
\hline Total viable bacteria & $2.09^{\mathrm{a}}$ & $1.75^{\mathrm{b}}$ & $1.70^{\mathrm{b}}$ & 0.102 & ${ }^{* *}$ \\
\hline Coliform bacteria & $\mathrm{N} . \mathrm{D}$ & $\mathrm{N} . \mathrm{D}$ & $\mathrm{N} . \mathrm{D}$ & - & - \\
\hline Proteolytic bacteria & $0.974^{\mathrm{a}}$ & $0.952^{\mathrm{a}}$ & $0.921^{\mathrm{a}}$ & 0.307 & N.S \\
\hline Lipolytic bacteria & $0.976^{\mathrm{a}}$ & $0.654^{\mathrm{a}}$ & $0.914^{\mathrm{a}}$ & 0.294 & ${ }^{* *}$ \\
\hline Yeasts and moulds & $0.593^{\mathrm{ab}}$ & $0.710^{\mathrm{a}}$ & $0.477^{\mathrm{b}}$ & 0.264 & ${ }^{*}$ \\
\hline
\end{tabular}

Means within each row bearing the same superscripts are not significantly different $(P>0.05)$

${ }^{1}$ Brands $A, B$ and $C$ refer to the three different types of processed cheese available in the market

** $=P<0.01$

* $=\mathrm{P}<0.05$

N.S $=$ Not significant

$S . L=$ Significant level

$\mathrm{SE}=$ Standard error of means

ND: Not detected 
Am. J. Food. Nutr, 2011, 1(1): 28-33 
Am. J. Food. Nutr, 2011, 1(1): 28-33

Table 3. Chemical composition (\%) of processed cheese in three brands collected in three monthly batches (Mean \pm SE)

\begin{tabular}{|l|l|c|c|c|c|c|}
\hline \multirow{3}{*}{ Batch } & \multirow{2}{*}{ Brand } & \multicolumn{5}{|c|}{ Chemical composition (\%) } \\
\cline { 3 - 7 } & & Fat & Protein & Moisture & Ash & $\begin{array}{c}\text { Titratable } \\
\text { acidity }\end{array}$ \\
\hline \multirow{4}{*}{1} & A & $29.33 \pm 0.352^{\mathrm{a}}$ & $8.65 \pm 0.134^{\mathrm{a}}$ & $49.33 \pm 0.458^{\mathrm{a}}$ & $2.70 \pm 0.158^{\mathrm{a}}$ & $0.653 \pm 0.013^{\mathrm{a}}$ \\
\cline { 2 - 7 } & B & $29.33 \pm 0.352^{\mathrm{a}}$ & $8.93 \pm 0.134^{\mathrm{a}}$ & $49.83 \pm 0.458^{\mathrm{a}}$ & $2.68 \pm 0.158^{\mathrm{a}}$ & $0.600 \pm 0.013^{\mathrm{a}}$ \\
\cline { 2 - 7 } & C & $29.00 \pm 0.352^{\mathrm{a}}$ & $8.98 \pm 0.134^{\mathrm{a}}$ & $50.17 \pm 0.458^{\mathrm{a}}$ & $2.50 \pm 0.158^{\mathrm{a}}$ & $0.707 \pm 0.013^{\mathrm{a}}$ \\
\cline { 2 - 7 } & S.L & N.S & N.S & N.S & N.S & N.S \\
\hline \multirow{4}{*}{2} & A & $29.83 \pm 0.352^{\mathrm{a}}$ & $8.68 \pm 0.134^{\mathrm{a}}$ & $51.33 \pm 0.458^{\mathrm{a}}$ & $2.67 \pm 0.158^{\mathrm{a}}$ & $0.693 \pm 0.013^{\mathrm{a}}$ \\
\cline { 2 - 7 } & B & $29.83 \pm 0.352^{\mathrm{a}}$ & $8.73 \pm 0.134^{\mathrm{a}}$ & $50.83 \pm 0.458^{\mathrm{a}}$ & $2.70 \pm 0.158^{\mathrm{a}}$ & $0.720 \pm 0.013^{\mathrm{a}}$ \\
\cline { 2 - 7 } & C & $29.33 \pm 0.352^{\mathrm{a}}$ & $8.90 \pm 0.134^{\mathrm{a}}$ & $51.50 \pm 0.458^{\mathrm{a}}$ & $2.65 \pm 0.158^{\mathrm{a}}$ & $0.680 \pm 0.013^{\mathrm{a}}$ \\
\cline { 2 - 7 } & S.L & N.S & N.S & N.S & N.S & N.S \\
\hline \multirow{4}{*}{3} & A & $29.17 \pm 0.352^{\mathrm{a}}$ & $9.00 \pm 0.134^{\mathrm{a}}$ & $53.67 \pm 0.458^{\mathrm{a}}$ & $2.85 \pm 0.158^{\mathrm{a}}$ & $0.627 \pm 0.013^{\mathrm{a}}$ \\
\cline { 2 - 7 } & B & $29.67 \pm 0.352^{\mathrm{a}}$ & $9.08 \pm 0.134^{\mathrm{a}}$ & $54.17 \pm 0.458^{\mathrm{a}}$ & $2.35 \pm 0.158^{\mathrm{b}}$ & $0.627 \pm 0.013^{\mathrm{a}}$ \\
\cline { 2 - 7 } & C & $29.67 \pm 0.352^{\mathrm{a}}$ & $8.53 \pm 0.134^{\mathrm{a}}$ & $53.33 \pm 0.458^{\mathrm{a}}$ & $2.71 \pm 0.158^{\mathrm{a}}$ & $0.613 \pm 0.013^{\mathrm{a}}$ \\
\cline { 2 - 7 } & S.L & N.S & N.S & N.S & & N.S \\
\hline
\end{tabular}

Means in each column bearing similar superscripts are not significantly different $(P>0.05)$

* $=\mathrm{P}<0.05$

N.S $=$ Not significant

S.L = Significance level

$\mathrm{SE}=$ Standard error of means

Table 4. Microbiological quality $\left(\log _{10}\right.$ cfu/gm) of processed cheese in three brands collected in three monthly batches (Mean \pm SE)

\begin{tabular}{|c|c|c|c|c|c|c|}
\hline \multirow[b]{2}{*}{ Batch } & \multirow{2}{*}{ Brand } & \multicolumn{5}{|c|}{ Microbiological count ( $\left.\log _{10} \mathrm{cfu} / \mathrm{gm}\right)$} \\
\hline & & $\begin{array}{c}\text { Total viable } \\
\text { bacteria }\end{array}$ & $\begin{array}{l}\text { Coliform } \\
\text { bacteria }\end{array}$ & $\begin{array}{c}\text { Proteolytic } \\
\text { bacteria }\end{array}$ & $\begin{array}{c}\text { Lipolytic } \\
\text { bacteria }\end{array}$ & $\begin{array}{c}\text { Yeasts and } \\
\text { moulds }\end{array}$ \\
\hline \multirow{4}{*}{1} & A & $2.40 \pm 0.013^{\mathrm{a}}$ & N.D & $0.933 \pm 0.034^{a}$ & $0.667 \pm 0.026^{b}$ & $1.113 \pm 0.077^{b}$ \\
\hline & B & $2.05 \pm 0.013^{b}$ & N.D & $0.947 \pm 0.034^{\mathrm{a}}$ & $0.833 \pm 0.026^{\text {ab }}$ & $1.173 \pm 0.077^{b}$ \\
\hline & C & $1.90 \pm 0.013^{b}$ & N.D & $1.033 \pm 0.034^{\mathrm{a}}$ & $1.000 \pm 0.026^{\mathrm{a}}$ & $1.430 \pm 0.077^{\mathrm{a}}$ \\
\hline & S.L & 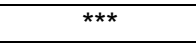 & - & N.S & $*$ & $*$ \\
\hline \multirow{4}{*}{2} & A & $2.33 \pm 0.013^{a}$ & N.D & $1.340 \pm 0.034^{\mathrm{a}}$ & $1.167 \pm 0.026^{a}$ & $0.167 \pm 0.077^{b}$ \\
\hline & B & $1.70 \pm 0.013^{b}$ & N.D & $1.310 \pm 0.034^{\mathrm{a}}$ & $0.217 \pm 0.026^{c}$ & $0.463 \pm 0.077^{\mathrm{a}}$ \\
\hline & C & $1.71 \pm 0.013^{b}$ & N.D & $0.883 \pm 0.034^{b}$ & $0.847 \pm 0.026^{b}$ & N.D \\
\hline & S.L & $\star * \star *$ & - & $*$ & ** & * \\
\hline \multirow{4}{*}{3} & A & $1.56 \pm 0.013^{\mathrm{a}}$ & N.D & $0.650 \pm 0.034^{b}$ & $1.093 \pm 0.026^{a}$ & $0.500 \pm 0.077^{\mathrm{a}}$ \\
\hline & B & $1.52 \pm 0.013^{\mathrm{a}}$ & N.D & $0.600 \pm 0.034^{b}$ & $0.913 \pm 0.026^{a}$ & $0.493 \pm 0.077^{\mathrm{a}}$ \\
\hline & C & $1.48 \pm 0.013^{\mathrm{a}}$ & N.D & $0.847 \pm 0.034^{\mathrm{a}}$ & $0.897 \pm 0.026^{a}$ & N.D \\
\hline & S.L & N.S & - & * & N.S & N.S \\
\hline
\end{tabular}

Means in each column bearing similar superscripts are not significantly different $(P>0.05)$

$*=\mathrm{P}<0.05$

$* * *=\mathrm{P}<0.001$

N.S = Not significant

S.L = Significance level

$\mathrm{SE}=$ Standard error of means

Table 5. Frequency of isolation of microbial species identified in the processed cheese

\begin{tabular}{|l|c|c|}
\hline Microorganism & No. of +ve samples & Percent of +ve samples \\
\hline Total viable bacteria & 27 & 100 \\
\hline Coliform bacteria & 0 & 0 \\
\hline Proteolytic bacteria & 21 & 77.8 \\
\hline Lipolytic bacteria & 20 & 74.2 \\
\hline Yeasts and moulds & 12 & 44.4 \\
\hline
\end{tabular}




\section{CONCLUSION}

This study concludes that the processed cheese available in the market is of good chemical and microbiological characteristics and that the standard procedures for its manufacture have been followed and implemented during the processing and storage conditions were favourable. Therefore, this product is safe for human consumption provided its storage and handling are done appropriately.

\section{REFERENCES}

Abdel Razig, K.A and Yousif, A.M (2010). Utilization of groundnut milk in manufacturing spread cheese. Pak. J. Nutr. 9(4):314-319.

Acharya, M.R and Mistry, V.V (2005). Effect of vacuumcondensed or ultrafiltered milk on pasteurized process cheese. J. Dairy Sci. 88:3037-3043.

Aly, M.E., Abdel-Baky, A.A and Farahat, S.M (1995). Quality of processed cheese spread made using ultrafiltered retentates treated with some ripening agents. Int. Dairy J. 5:191-209.

AOAC (1990). Official Methods of Analysis. Association of Official Analytical Chemists, Washington, DC, USA.

AOAC (2000). Official Methods of Analysis of AOAC International, $17^{\text {th }}$ ed., AOAC International, Gaitherburg, MD, USA, Official Methods 920.124, 926.08, 955.30, 2001.14.

Christen, G.L., Davidson, P.M., McAllister, J.S and Roth, L.A (1992). Coliform and other indicator bacteria. In :Marshall RT (ed): Standard Methods for the Examination of Dairy Products, $16^{\text {th }}$ edition, Ed.,. Washington, DC: American Public Health Association, pp 247-269.

Dimitreli, G and Thomareis, A.S (2007). Texture evaluation of block-type processed cheese as a function of chemical composition and in relation to its apparent viscosity. J. Food Eng. 79:1364-1373.

Frank, F.J., Christen, L. G. and Bullerman, L.B (1992). Tests for groups of microorganisms. In:Marshall RT (ed): Standard Methods for the Examination of Dairy Products, $16^{\text {th }}$ edition, Ed.,. Washington, DC: American Public Health Association, pp 271-286.

Hanna, S.A.S and Nader, A.S (1996). Manufacture of processed cheese from Iraqi white soft cheese. J. Soc. Dairy Technol. 49(2):57-58.

Houghtby, A.G., Maturin L.J and Koenig, K.E (1992). Microbiological count methods. In:Marshall RT (ed): Standard Methods for the Examination of Dairy Products, $16^{\text {th }}$ edition, Ed.,. Washington, DC: American Public Health Association, pp 213-246.
Kaminarides, S and Stachtiaris, S (2000). Production of processed cheese using Kassari cheese and processed cheese analogues incorporating whey protein concentrate and soybean oil. Int. J. Dairy Technol. 53(2):69-74.

Kapoor, R and Metzger, L.E (2008). Process cheese: scientific and technological aspects $-\mathrm{A}$ review. Comp. Rev. Food Sci. Food Safety 7:194-214.

Kapoor, R., Metzger, L.E., Biswas, A.C and Muthukummarappan, K (2007). Effect of natural cheese characteristics on process cheese properties. J. Dairy Sci. 90:1625-1634.

Kung, H., Tsai, Y., Hwang, C., Lee, Y., Hwang, J., Wei, C and Hwang, D (2005). Hygienic quality and incidence of histamine-forming Lactobacillus species in natural and processed cheese in Taiwan. J. Food Drug Anal. 13(1)51-56.

Kwak, H.S., Choi, S.S., Ahn, J and Lee, S.W (2002). Casein hydrolysare fractions act as emulsifiers in process cheese. J. Food Sci. 67(2):821-825.

Lee, S.K., Buwalda, R.J., Euston, S.R., Foegeding, E.A and McKenna, A.B (2003). Changes in the rhoelogy and microstructure of processed cheese during cooking. Lebensm.-Wiss. U.-Technol. 36:339-345.

Mayer, H.K (2001). Bitterness in processed cheese caused by an overdose of a specific emulsifying agent. Int. Dairy J. 11:533-542.

Nour El Diam, M.S.A and El Zubeir, I.E.M (2006). Comparison of microbiological quality of processed and non processed Sudanese white cheese. Res. J. Microbiol. 1(3):273-279.

Palmas, F., Cosentino, S., Fadda, M.E., Deplano, M and Mascia, V (1999). Microbial characteristics of Pecorino processed cheese spreads. Lait 79:607-613.

Pinto, S., Rathour, A.K., Prajapati, J.P., Jana, A.H and Solanky, M.J (2007). Utilization of whey protein concentrate in processed cheese spread. Natural Product Radiance 6(5):398-401.

Piska, I and Štětina, J (2004). Influence of cheese ripening and rate of cooling of the processed cheese mixture on rheological properties of processed cheese. J. Food Eng. 61:551-555.

Schär, W and Bosset, J.O (2002). Chemical and physicochemical changes in processed cheese and readymade fondue during storage. A review. Lebensm.Wiss. U.-Technol. 35:15-20.

Shirashoji, N., Jaeggi, J.J and Lucey, J.A (2006). Effect of trisodium citrate concentration and cooking time on the physicochemical properties of pasteurized process cheese. J. Dairy Sci. 89:15-28.

Zaki,S.A. (1988). Application of Practical Microbiology. DarELmaarif (inArabic), Egypt. 